\title{
COMPORTAMENTO E TIPOLOGIA DO EMPREENDEDOR DIANTE DO INSUCESSO EMPRESARIAL
}

\author{
ENTREPRENEURIAL BEHAVIOR AND TYPOLOGY \\ IN THE FACE OF BUSINESS FAILURE \\ Ítalo Fernando Minello ${ }^{1}$ e Laura Alves Scherer ${ }^{2}$
}

Recebido em: 17/05/2012

Aprovado em: 22/08/2013

\section{RESUMO}

Com o objetivo de analisar as mudanças de comportamento e tipologia de empreendedores que vivenciaram o insucesso empresarial, o presente estudo apresenta uma abordagem sobre empreendedor, tipologias de empreendedor, insucesso empresarial e comportamento do empreendedor diante do insucesso. As tipologias apresentadas têm como base características comportamentais de empreendedores e são sustentadas por Miner (1996), Vesper (1980) e Filion (1999). Esta pesquisa caracteriza-se como exploratória e, por meio de entrevistas semiestruturadas com sete empreendedores que vivenciaram a descontinuidade dos seus negócios, analisa as mudanças comportamentais da tipologia dos empreendedores de forma qualitativa, com base na técnica de análise de conteúdo. As categorias encontradas através dos relatos - excesso de autoconfiança, falta de conhecimento em administração, sofrimento emocional, problemas com os sócios, apoio externo e processo de aprendizagem - são comportamentos que os empreendedores apresentaram antes, durante e depois do insucesso empresarial e estão relacionadas com as tipologias de empreendedor. Destaca-se que o insucesso empresarial afetou a vida dos empreendedores, no entanto, isso aconteceu de maneira singular para cada indivíduo.

Palavras-chave: Comportamento empreendedor; Tipologia de empreendedor; Insucesso empresarial.

\begin{abstract}
In order to analyze the changes in behavior and typology of entrepreneurs who have experienced business failure, this study presents an approach about: entrepreneur, entrepreneurial typologies, business failure and entrepreneurial behavior in the face of failure. The typologies are based on behavioral characteristics of entrepreneurs and are supported by Miner (1996), Vesper (1980) and Filion (1999). This research is characterized as exploratory, uses semistructured interviews with seven entrepreneurs who have experienced the disruption of their business and analyzes the changes of behavior and typology of entrepreneurs in a qualitative way, by applying the technique of content analysis. The categories found by the reports - over self-confidence, lack of knowledge in management, emotional distress, problems with partners, external support and learning process - are characterized as behaviors that entrepreneurs had before, during and after business failure and are related to the types of entrepreneur. It is noteworthy that the business failure has affected the entrepreneur's lives, however, it happened in a unique way for each individual.
\end{abstract}

Keywords: Entrepreneurial behavior; Entrepreneur typology; Business failure.

\footnotetext{
${ }^{1}$ Doutor em Administração pela Universidade de São Paulo (USP), Brasil. Professor do Departamento de Administração da Universidade Federal de Santa Maria (UFSM). E-mail: italo.minello@uol.com.br.

${ }^{2}$ Mestre em Administração pela Universidade Federal de Santa Maria (UFSM), Brasil. Professora Substituta do Eixo de Gestão e Negócios do Instituto Federal Farroupilha - Campus São Vicente do Sul (IFF-SVS). E-mail: laurascherer@ymail.com.
} 


\section{Introdução}

As pesquisas acadêmicas na área de empreendedorismo apresentaram um crescimento nas últimas duas décadas (FLECK, 2009). Para os investigadores dessa área, o empreendedor é um elemento importante a ser estudado no contexto da mudança organizacional, pois suas características comportamentais também podem ser alteradas por tranformações no ambiente, como quando há transição do sucesso para o insucesso empresarial. A maioria dos estudos organizacionais de novos empreendimentos tem como foco os casos de sucesso, sendo limitadas as pesquisas sobre insucesso (ZACHARIS; MEYER; DE CASTRO, 1999).

O insucesso é, na maioria das vezes, algo para o qual o empreendedor não está preparado. Cabe salientar que o empreendedor que está à frente da organização precisa adaptar o seu negócio às mudanças de fatores internos e externos, assim como modificar suas características e seu comportamento que interferem diretamente no direcionamento para o sucesso ou insucesso empresarial. Para facilitar o estudo dessas características, muitos autores desenvolvem tipologias, propostas mediante a combinação de particularidades comportamentais do empreendedor em face do seu negócio, tipologias essas que norteiam este estudo.

Apesar de o insucesso ser um tema instigante e desafiador, verifica-se que ainda é pouco explorado na literatura. Tendo isso em vista, este estudo pretende contribuir para a compreensão do comportamento humano em situações de insucesso. Assim, o objetivo deste estudo é analisar as mudanças de comportamento e tipologia dos empreendedores antes, durante e depois do insucesso empresarial.

Cabe destacar que este trabalho tem como base o resultado das experiências de insucesso de empreendedores e como foco de estudo as mudanças de comportamento e de tipologia de empreendedor propostas por autores da área do empreendedorismo, como Miner (1996), Vesper (1980) e Filion (1999).

\section{Referencial teórico}

\subsection{Empreendedor}

Um dos primeiros autores a utilizar o termo empreendedor foi Schumpeter (1984), que o define como aquele que quebra a ordem e inova, introduz novos produtos e serviços pela criação de formas de organização ou pela exportação de novos recursos e identifica oportunidades no mercado, promovendo o desenvolvimento e o crescimento econômico. Dornelas (2008) amplia o pensamento de Schumpeter quando acrescenta ao conceito variáveis que envolvem as funções, atividades e ações associadas com a criação de novas empresas por parte do empreendedor. Para esse autor, identificar o empreendedor como um indivíduo que possui características inovadoras, que transforma conhecimento e bens em novos produtos, pode ter se tornado algo prático para a sociedade. Nesse contexto, cabe salientar, segundo Baron e Shane (2007), que definições são sempre traiçoeiras e, principalmente no que tange ao empreendedorismo, a tarefa torna-se ainda mais complexa, pois se verifica uma falta de consenso sobre sua definição na literatura.

De acordo com Dolabela (1999), os empreendedores criam um novo modelo de sistemas de valores no meio social, no qual os comportamentos individuais são fundamentais. As culturas, as necessidades e os hábitos de uma região influenciam o comportamento, sendo os seres humanos, portanto, produtos do ambiente em que vivem. Nesse sentido, destaca-se a abordagem de Filion (1999), a qual pressupõe que o comportamento do empreendedor é um fenômeno regional, ou seja, é fruto da interação social, econômica e cultural. Assim, os 
empreendedores buscam integrar, assimilar e interpretar esses comportamentos e isso parece refletir na maneira como agem em suas empresas.

Levando em consideração que o ambiente influencia o desenvolvimento do comportamento do empreendedor, Filion (1999) relata que as pessoas têm mais chance de tornarem-se empreendedoras se houver um modelo na sua família ou no seu meio. Para o autor, quando as pessoas tornam-se empreendedoras, a natureza da atividade leva-as ao desenvolvimento de certas características, como a tenacidade e a criatividade para permanecerem em sua área de atuação. Hisrich e Peters (2004) corroboram essa ideia ao afirmar que não existe um perfil empresarial ideal; os empreendedores provêm de experiências educacionais, situações familiares e vivencias profissionais variadas, diferenciando-se um do outro.

No presente estudo, o conceito utilizado de empreendedor está relacionado ao comportamento desse indivíduo. Assim, empreendedor é aquele que desenvolve algo inovador, tem iniciativa e capacidade de organizar e reorganizar mecanismos sociais e econômicos a fim de transformar recursos e situações para proveito prático e aceita os riscos ou o fracasso de suas ações (MINELLO, 2010).

Contudo, evidencia-se que, assim como o ser humano é singular em sua essência, o empreendedor também o é no que se refere à sua atuação dentro do contexto organizacional. Nessa perspectiva, destaca-se o surgimento de diferentes tipologias para um empreendedor, que foram criadas a partir das características que são abordadas por diferentes autores, conforme apresentado a seguir.

\subsection{Tipologias de empreendedor}

Segundo Resende (2008), as pessoas têm comportamentos diferentes em função de diversos fatores, como: fisiologia, temperamentos, aptidões, habilidades desenvolvidas ao longo da vida dependendo de situações, dificuldades e desafios enfrentados. No caso do estudo de empreendedores, muitos autores classificam o comportamento desses indivíduos em tipologias.

No intuito de contribuir para a compreensão das tipologias, são apresentadas três tipologias distintas baseadas no comportamento dos empreendedores. A primeira tipologia abordada é a de Miner (1996), que partiu das pesquisas de Collins e Moore, feita em 1965, e de Smith, realizada em 1967, sustentando a ideia de que existe uma relação direta entre a personalidade do indivíduo e o potencial para o seu sucesso empresarial. O autor desenvolveu um estudo com 100 empreendedores, aplicando testes psicológicos e questionários, que resultaram em uma classificação de quatro tipos de empreendedores, visualizada no Quadro 1.

\begin{tabular}{|c|l|}
\hline $\begin{array}{c}\text { Tipo de } \\
\text { Empreendedor }\end{array}$ & \multicolumn{1}{c|}{ Características Comportamentais } \\
\hline $\begin{array}{c}\text { Empreendedor } \\
\text { pessoal }\end{array}$ & $\begin{array}{l}\text { Procura ser bom em tudo o que faz, possui iniciativa e comprome- } \\
\text { timento com a empresa e tenta trabalhar baseado no planejamento e } \\
\text { estabelecimento de objetivos pessoais. }\end{array}$ \\
\hline $\begin{array}{c}\text { Especialista } \\
\text { gerador de ideia }\end{array}$ & $\begin{array}{l}\text { Busca inovar e procura atingir as estratégias da empresa através de } \\
\text { novos produtos, novos nichos e novos processos; possui um bom } \\
\text { grau de inteligência e desejo por ideias e tenta não correr riscos. }\end{array}$ \\
\hline $\begin{array}{c}\text { Empático } \\
\text { supervendedor }\end{array}$ & $\begin{array}{l}\text { Acredita que a via para o sucesso empresarial é a força das vendas, } \\
\text { leva em consideração os processos sociais, o bom relacionamento } \\
\text { com os indivíduos e procura compreendê-los }\end{array}$ \\
\hline Verdadeiro gestor & $\begin{array}{l}\text { Procura adaptar-se para gerir um cargo de alta chefia, tem desejo pelo } \\
\text { poder, relaciona-se de maneira satisfatória com as autoridades, busca } \\
\text { a competição empresarial e possui uma boa capacidade decisória. }\end{array}$ \\
\hline
\end{tabular}

Quadro 1 - Tipologia do empreendedor com base em Miner (1996)

Fonte: Adaptado de Miner (1996). 
A segunda tipologia é a de Vesper (1980), baseada nas diferentes formas de atuação dos empreendedores. Para o autor, a tipologia do empreendedor muda conforme os meios de operação. Nesse sentido, são apresentadas as onze categorias de Vésper (1980), detalhadas no Quadro 2.

\begin{tabular}{|c|c|}
\hline $\begin{array}{c}\text { Tipo de } \\
\text { Empreendedor }\end{array}$ & Características Comportamentais \\
\hline Autônomo & Executa seus serviços pessoalmente, baseando-se em habilidade técnica. \\
\hline $\begin{array}{l}\text { Formador } \\
\text { de equipe }\end{array}$ & $\begin{array}{l}\text { Contrata outras pessoas e delega tarefas, formando equipes e perce- } \\
\text { bendo uma possível vantagem na expansão do negócio. }\end{array}$ \\
\hline $\begin{array}{l}\text { Inovador } \\
\text { independente }\end{array}$ & Cria novos produtos e criaria empresas para desenvolvê-los. \\
\hline $\begin{array}{l}\text { Multiplicador } \\
\text { de padrão }\end{array}$ & $\begin{array}{l}\text { Reconhece um negócio passível de ser multiplicado visando a ob- } \\
\text { tenção de lucro. }\end{array}$ \\
\hline $\begin{array}{l}\text { Explorador de } \\
\text { economia de escala }\end{array}$ & $\begin{array}{l}\text { Cria seus negócios baseado em preços menores obtidos devido à } \\
\text { economia de escala, localização em áreas mais baratas e/ou existên- } \\
\text { cia de impostos menores. }\end{array}$ \\
\hline $\begin{array}{l}\text { Agregador } \\
\text { de capital }\end{array}$ & $\begin{array}{l}\text { Capta recursos de diversas fontes para bancar a operação de bancos, } \\
\text { seguradoras entre outras. }\end{array}$ \\
\hline Aquisidor & Opta por adquirir negócios que já estão em processo de operação. \\
\hline $\begin{array}{l}\text { Especialista de } \\
\text { compra e venda }\end{array}$ & $\begin{array}{l}\text { Compra empresas em dificuldades, recupera-a do fracasso e depois } \\
\text { vende-a por um preço maior. }\end{array}$ \\
\hline $\begin{array}{l}\text { Formador de } \\
\text { conglomerados }\end{array}$ & $\begin{array}{l}\text { Trabalha a fim de obter controle acionário de uma empresa para, a } \\
\text { partir desta, adquirir o controle de outras empresas. }\end{array}$ \\
\hline Especulador & Dedica-se à compra e venda de commodities ou da área imobiliária. \\
\hline $\begin{array}{l}\text { Manipulador de } \\
\text { valor aparente }\end{array}$ & $\begin{array}{l}\text { Adquire bens ou empresas baratas, melhorando sua aparência ou } \\
\text { seus índices financeiros para revendê-los com elevação no preço. }\end{array}$ \\
\hline
\end{tabular}

A terceira tipologia, exposta a seguir, foi apresentada por Filion (1999) a partir de pesquisas de outros autores filiados a várias disciplinas das ciências humanas. Em seu estudo sobre empreendedorismo com proprietáriosgerentes de pequenas empresas, Fillion identificou diferentes tipos de empreendedores, os quais são apresentados em seis categorias no Quadro 3.

\begin{tabular}{|c|l|}
\hline $\begin{array}{c}\text { Tipo de Em- } \\
\text { preendedor }\end{array}$ & \multicolumn{1}{c|}{ Características Comportamentais } \\
\hline O lenhador & $\begin{array}{l}\text { Caracteriza-se por gostar de fazer as coisas e sente-se como se estivesse } \\
\text { perdendo tempo quando têm de falar com pessoas. Enquanto empregador, } \\
\text { prefere as pessoas que trabalham durante muitas horas como eles mesmos. } \\
\text { A cultura organizacional do seu empreendimento é voltada para a produ- } \\
\text { ção. }\end{array}$ \\
\hline O sedutor & $\begin{array}{l}\text { É aquele que se entrega de maneira completa e emocional aos negócios, } \\
\text { mas seu entusiasmo nunca dura muito. Cria negócios e logo os vende, pois } \\
\text { gosta que as coisas aconteçam rápido. Enxerga tudo sob um ponto de vista } \\
\text { bem particular: onde e como ter lucros com o menor esforço possível. }\end{array}$ \\
\hline O jogador & $\begin{array}{l}\text { Percebe o esporte e o lazer como elemento vital. Considera a empresa } \\
\text { como um suporte financeiro, um meio de ganhar o suficiente para fazer } \\
\text { o que realmente quer. Opta por campos de atuação sazonais, trabalhando } \\
\text { muito durante certos períodos, mas não em outros. Não está, de maneira } \\
\text { absoluta, comprometido emocionalmente com o negócio. }\end{array}$ \\
\hline
\end{tabular}


(continuação)

\begin{tabular}{|c|l|}
\hline O hobbysta & $\begin{array}{l}\text { Dedica toda a sua energia e o seu tempo livre aos negócios. Frequente- } \\
\text { mente, possui outro emprego oficial, mas só o mantém como um apoio } \\
\text { financeiro para seu negócio, que é seu hobby. É nele que vê a possibilidade } \\
\text { de autorrealização, motivo pelo qual investe todos os recursos para desen- } \\
\text { volvê-lo. }\end{array}$ \\
\hline O convertido & $\begin{array}{l}\text { Procura alguma coisa com que se realize e, quando encontra o que busca- } \\
\text { va, sua vida gira em torno dessa descoberta. Prefere ver a si mesmo como } \\
\text { uma pessoa particularmente superior, ao invés de ver os resultados. Gosta } \\
\text { de estar no controle, por isso têm dificuldade de delegar algo a outra pessoa } \\
\text { até que esta prove ser merecedora confiança. }\end{array}$ \\
\hline O missionário & $\begin{array}{l}\text { Conhece muito bem o produto e o mercado. Leva em consideração a evo- } \\
\text { lução e o aprendizado dos indivíduos, compreende o negócio como um } \\
\text { sistema social e acredita que os resultados dependem da capacidade de } \\
\text { trabalho em equipe. Delega afazeres ao máximo, participa de atividades } \\
\text { em força-tarefa, onde possa escutar, discutir e trocar experiências. }\end{array}$ \\
\hline
\end{tabular}

Quadro 3 - Tipologia do empreendedor com base em Filion (1999)

Fonte: Adaptado de Filion (1999).

As seis categorias apresentadas por Filion (1999) fecham o estudo das três tipologias de empreendedor enfocadas neste trabalho. Para Filion (1999), as tipologias possibilitam uma base para a compreensão dos valores e do pensamento empresarial, bem como do comportamento do empreendedor. Porém, deixa claro que nenhuma tipologia é capaz de abarcar todos os tipos de empreendedores existentes, pois cada caso pode ser considerado único.

Nesse sentido, com o intuito de relacionar as características comportamentais de empreendedores determinantes das tipologias e entender o contexto que os empreendedores deste estudo vivenciaram, será apresentada, a seguir, a literatura sobre o insucesso empresarial e sobre o comportamento do empreendedor diante desse insucesso.

\subsection{Insucesso empresarial}

Na literatura sobre negócios, encontram-se inúmeros casos de empresas que obtiveram sucesso, no entanto, os estudos sobre insucesso são pouco explorados (ZACHARAKIS; MEYER; DE CASTRO, 1999), mesmo que casos de insucesso sejam frequentes na prática (GEM, 2010). De acordo com Robinson (2007), os fracassos nos empreendimentos são um aspecto importante da economia a ser estudado, mas são de difícil análise devido à diversidade de definições de fracasso nos negócios, às suas várias causas de encerramento e à falta de dados abrangentes.

Contudo, o empreendedor tem como objetivo o sucesso de sua organização. Os estudos sobre como isso pode ocorrer apresentam vários conceitos de sucesso. Ferreira (1999) define sucesso como aquilo que teve bom êxito após sua conclusão.

Ainda sobre essa temática, Greatti (2003) evidencia que por trás do sucesso de uma empresa há uma boa ideia e alguém com talento e disposição suficientes para transformá-la em realidade. Esse comportamento é característica do empreendedor, que, na visão de Minello (2010), é aquele que tem iniciativa de correr riscos, organizar e reorganizar mecanismos sociais e econômicos a fim de transformar recursos e situações para proveito prático. Contudo, a mesma pessoa que administra um empreendimento que vem obtendo resultados positivos pode levá-lo ao declínio se não dispor de energia suficiente para mapear a complexidade do ambiente no qual seu negócio está inserido, o que poderá causar o insucesso do seu empreendimento (WHETTEN, 1980).

Outros pesquisadores, como Bruno, Leidecker e Harder (1986), também 
têm estudado os fenômenos de sobrevivência de novos empreendimentos sob a perspectiva do empreendedor.Esses autores investigaram empresas de alta tecnologia da Califórnia do Norte estabelecidas em dois períodos: 1960 e 1980 . Os pesquisadores procuraram identificar as causas do fracasso, realizando entrevistas com diversos empreendedores que vivenciaram tal experiência.Os resultados dessa investigação proporcionaram a descoberta de que as causas percebidas eram as mesmas nos dois períodos de tempo: causas internas, como a própria gestão, e causas externas, como o produto/mercado e o financiamento (ZACHARAKIS; MEYER; DE CASTRO, 1999).

Cabe salientar que, na pesquisa mencionada, mesmo em épocas distintas os fatores que causam o insucesso são problemas externos ou de gestão e que os empreendedores e financiadores daqueles empreendimentos também compartilham desse pensamento. Os empreendedores, com mais frequência, atribuem o fracasso a fatores externos, tais como condições de mercado competitivo e problemas de financiamento; ao passo que os financiadores, por sua vez, atribuem o fracasso a fatores internos, como, por exemplo, a problemas de gestão (ZACHARAKIS; MEYER; DE CASTRO, 1999).

Apesar da existência de diferentes perspectivas sobre o insucesso empresarial, o presente estudo optou pela adoção do conceito de Bruno, Mcquarrie e Torgrimson (1992), que o define como uma descontinuidade do negócio, que pode ser oriunda de várias causas. Entre elas, os autores destacam: problemas legais, disputas na sociedade, morte ou mudança de interesses. A escolha dessa definição ocorreu em função do seu alinhamento com o objetivo deste trabalho, permitindo analisar as mudanças de comportamento e de tipologia do empreendedor antes, durante e depois do insucesso.

Nesse contexto, tanto advindo de fatores externos quanto de problemas na gestão, o insucesso do negócio também vai influenciar as características do em- preendedor e do seu comportamento ou ser influenciado por elas. Na visão de Pereira (1995), o que diferencia fracasso de sucesso são as características, capacidades e habilidades individuais do empreendedor diante das adversidades.

\subsection{Comportamento do empreendedor diante do insucesso}

A partir do momento em que o empreendedor é questionado sobre as causas pelas quais seus negócios fracassaram, percebe-se que a responsabilidade pelo insucesso é justificada por fatores externos ao negócio, tais como, o governo, a economia, os juros bancários, a falta de clientes e a deslealdade dos sócios (PEREIRA, 1995; ZACHARAKIS; MEYER; DE CASTRO, 1999). Para Pereira (1995), parece haver certo grau de miopia por parte dos empreendedores por colocarem a culpa em terceiros pelo seu fracasso, uma vez que, embora esses empreendedores acreditem estar certos a respeito de tudo, o que ocorre, normalmente, é que a culpa está atrelada aos seus próprios erros. Segundo Finkelstein $(2004,2007)$, a razão da maioria dos fracassos pode não ser a inexistência de capacidade, mas a percepção, por parte da empresa e de seus dirigentes, de sua excelência e autoconfiança, a qual pode provocar uma dificuldade na adaptação da empresa às mudanças ambientais. Dessa forma, Dotlich e Cairo (2003) fazem referência à questão comportamental e perceptiva por parte dos executivos que falham, ressaltando que as causas dos problemas estão relacionadas ao que eles fazem, às suas decisões e a quem eles são.

Baseado em pesquisa realizada com dirigentes norte-americanos, Flinkelstein $(2004,2007)$, ao discutir essa visão comportamental do empreendedor diante do insucesso, identifica sete hábitos dos executivos malsucedidos. $\mathrm{O}$ primeiro é a crença do líder de possuir o total domínio de seu ambiente, utilizando as pessoas como instrumento. $\mathrm{O}$ se- 
gundo hábito é a completa identificação do líder com a empresa, o que faz com que cumpram suas ambições pessoais, utilizando-se dos recursos corporativos. Outros hábitos citados por Finkelstein $(2004,2007)$ relacionam-se ao aspecto de os executivos pensarem que possuem todas as respostas; subestimarem obstáculos; terem obsessão pela imagem da empresa; eliminarem pessoas que não os apoiem na tomada de decisão; e basearem as decisões da empresa no que já funcionou, não considerando inovações importantes.

$\mathrm{Na}$ pesquisa de Minello (2010), é detalhado o processo de resiliência de empreendedores que vivenciaram o insucesso empresarial. $\mathrm{O}$ autor analisa comparativamente três momentos - antes, durante e depois do insucesso -, identificando características comportamentais distintas dos empreendedores em cada um dos momentos e destacando que esses alteraram seu comportamento durante o processo de fracasso e depois o alteraram novamente após essa vivência.

Minello (2010), ao considerar o comportamento dos entrevistados na linha do tempo, constata que, antes da descontinuidade do negócio, o empreendedor não media as consequências de suas ações, acreditando que poderia resolver qualquer situação. Durante a descontinuidade, houve alteração no seu comportamento, como a atribuição da responsabilidade sobre sua realidade a outros e não a ele mesmo, a busca desesperada para reverter a situação de adversidade e até mesmo características de ideação suicida. Fechando o ciclo de comportamento, depois do insucesso, emerge o processo de aprendizagem, em que os empreendedores passaram a se questionar mais, referenciando-se com humor à experiência de fracasso, parecendo estar mais aptos a planejar suas ações de maneira mais realista.

\section{Método de pesquisa}

Este estudo caracteriza-se como uma pesquisa qualitativa. A abordagem qualitativa justifica-se por ser adequada a situações que buscam compreender aspectos psicológicos relacionados ao fenômeno em estudo (RICHARDSON, 2008), como as mudanças na tipologia de empreendedores em situações de insucesso.

A aparente escassez de abordagem sobre o tema sustenta uma pesquisa exploratória, que, de acordo com Cooper e Schindler (2003), é adequada quando os pesquisadores não têm uma ideia clara dos problemas enfrentados pelo pesquisado. Na visão de Sampieri et al. (2006), o estudo de cunho exploratório é utilizado quando se busca examinar um tema ou problema de pesquisa pouco estudado, que apresenta dúvidas ou ainda foi pouco abordado.

A unidade de análise do presente estudo foi composta por sete empreendedores da Grande São Paulo que vivenciaram o insucesso empresarial e conseguiram superá-lo, os quais foram denominados de E1 a E7. Essa superação pode ter sido mudança de carreira profissional, criação de um novo empreendimento ou realização de alguma outra atividade através da qual tenha alcançado satisfação pessoal ou profissional.

A coleta de dados foi feita a partir de entrevistas semiestruturadas, gravadas e transcritas, com duração de aproximadamente uma hora e trinta minutos, realizadas a partir de um roteiro que permitiu o levantamento de dados referentes a diferentes momentos - antes, durante e depois do insucesso empresarial. As perguntas foram seccionadas em quatro blocos: quanto à história de vida, quanto à trajetória profissional, quanto ao processo de descontinuidade e quanto ao processo de resiliência.

Como técnica de análise dos dados, utilizou-se a análise de conteúdo, especificamente a análise categorial e de enunciação. De acordo com Bardin (2011), a análise de conteúdo é um 
conjunto de técnicas de análise das comunicações visando obter indicadores que permitam a inferência de conhecimentos relativos às mensagens. Nas entrevistas realizadas, buscou-se identificar as características que compõem o comportamento e a tipologia de cada empreendedor antes, durante e depois do insucesso empresarial e verificar se houve alteração dessas tipologias durante esses períodos. As categorias de análise foram definidas não a priori, o que significa que emergiram a partir do relato dos entrevistados.

As análises foram assim efetuadas:

1. Caracterização do Perfil Empreendedor dos Entrevistados - neste artigo exemplificado pelo E1;

2. Caracterização das Tipologias dos
Empreendedores - antes, durante e depois do insucesso empresarial;

3. Apresentação das Categorias de Análise Não a Priori;

4. Análise das Categorias Não a Priori e das Tipologias;

5. Apresentação da Figura Síntese da Pesquisa.

\section{Apresentação e análise dos resultados}

Primeiramente, foi realizada a caracterização do perfil empreendedor para cada um dos entrevistados, assim como uma análise de suas características de empreendedor. Em função da limitação de espaço, neste estudo a caracterização do perfil foi exemplificada por E1.

\begin{tabular}{|c|c|}
\hline Entrevistado 1 (E1) & Trechos da fala de E1 \\
\hline $\begin{array}{l}\text { Características do } \\
\text { empreendedor }\end{array}$ & $\begin{array}{l}\text { "quando eu estava trabalhando de empregado, eu já desem- } \\
\text { penhava o processo da serralheria para o proprietário, ele } \\
\text { deixava tudo na minha mão e ia para chácara, e eu que as- } \\
\text { sumia a responsabilidade da serralheria então eu me via, já } \\
\text { sendo um empreendedor". } \\
\text { "Então eu iniciei um negócio de coisas usadas, e foi o início } \\
\text { de todo o meu crescimento. Aí aquilo foi me alavancando... } \\
\text { eu dei seguimento e fui, peguei o fornecedor que era difícil } \\
\text { de ter. E deu continuidade nesse, nesse ramo, e fui crescen- } \\
\text { do, fui crescendo, na minha casa, logo aluguei um terreno na } \\
\text { avenida, porque o salão era muito difícil, construí um salão } \\
\text { na propriedade dos outros, e iniciei uma loja dentro do salão } \\
\text { que eu mesmo construí, o aluguel barato, visualizei a longo } \\
\text { prazo, construí e fui fiz um salão na avenida, e hoje minha } \\
\text { esposa toma conta, tá indo muito bem, e eu já to iniciando } \\
\text { uma nova fase, que é uma agência de automóveis, já tenho } \\
\text { alguns carros pra vender, aonde minha esposa toma conta do } \\
\text { brechó, aonde foi o início de tudo". }\end{array}$ \\
\hline $\begin{array}{l}\text { Análise das características } \\
\text { do empreendedor }\end{array}$ & $\begin{array}{l}\text { E1 apresentou responsabilidades de um empreendedor desde } \\
\text { quando trabalhava como empregado; mostrou iniciativa ao } \\
\text { propor uma sociedade no brechó identificando uma oportu- } \\
\text { nidade no mercado; assumiu riscos ao iniciar um negócio } \\
\text { ousado, com fornecedor difícil de ter; e demonstrou que pos- } \\
\text { sui visão de crescimento ao expandir suas atividades com } \\
\text { outro negócio paralelo ao brechó. }\end{array}$ \\
\hline
\end{tabular}

Quadro 4 - Exemplo de Caracterização dos Perfis dos Entrevistados

Fonte: Pesquisa. 
A partir dos objetivos apresentados no início deste estudo, analisa-se a mudança do comportamento dos empreendedores antes, durante e depois do insucesso empresarial e define-se, assim, a tipologia mais adequada para cada empreendedor com base no referencial teórico adotado. Para justificar essa tipologia, foi feita a caracterização a partir dos trechos das entrevistas dos empreendedores, que se encontra nos quadros a seguir.

\begin{tabular}{|c|c|c|}
\hline \multicolumn{3}{|c|}{ Antes do insucesso empresarial } \\
\hline Tipologia & Caracterização & Empreededor \\
\hline Autônomo & $\begin{array}{l}\text { "Sempre fui esforçado, sempre me dediquei bastante na- } \\
\text { quilo que eu to fazendo é, então aprendi rapidamente a fa- } \\
\text { zer portão, grade. E daí com } 17 \text { anos, aproximadamente, } \\
\text { eu iniciei a minha própria serralheria, pedi a conta ele me } \\
\text { deu a máquina de solda, uma máquina de corte, e eu ini- } \\
\text { ciei com essas ferramentas que esse serralheiro havia me } \\
\text { dado". }\end{array}$ & E1 \\
\hline $\begin{array}{l}\text { Multiplicador } \\
\text { de padrão }\end{array}$ & $\begin{array}{l}\text { "... A primeira empresa que eu abri, na verdade a primeira } \\
\text { coisa que eu fiz no passado, foi ter uma, uma academia de } \\
\text { ginástica, gostava muito, e eu falei: ah, na cidade não tem, } \\
\text { vou montar uma. Montei". }\end{array}$ & $\mathrm{E} 2$ \\
\hline \begin{tabular}{|c|} 
\\
Empreendedor \\
pessoal
\end{tabular} & $\begin{array}{l}\text { "Eu e um amigo, Carlos, antes de eu sair, ele trabalhava na } \\
\text { empresa na cobrança, daí eu sai, ele saiu primeiro, e foi tra- } \\
\text { balhar, ele me convidou pra fazer sociedade em três meses } \\
\text { nós ganhamos dinheiro e compramos uma lojinha pequena } \\
\text { de material de construção e aí compramos. Demos setenta } \\
\text { por cento de entrada, oitenta por cento, e eu tinha um cor- } \\
\text { cel e na época ele tinha uma kombi e, vendemos e com- } \\
\text { pletamos o dinheiro e o restante compramos de material } \\
\text { em uma loja pequeninha, tinha um caminhão e uma kombi } \\
\text { apenas, e entrei num ramo de construção né?!". }\end{array}$ & E3 \\
\hline $\begin{array}{l}\text { Empreendedor } \\
\text { pessoal }\end{array}$ & $\begin{array}{l}\text { "Na época eu fui empregado, visualizando opções o cres- } \\
\text { cimento é a experiência positiva dos meus patrões e a } \\
\text { oportunidade que surgiu no mercado, pra eu entrar acho } \\
\text { que aí eu senti no momento e falei é agora, vou entrar por- } \\
\text { que acho que é a minha vez". }\end{array}$ & E4 \\
\hline \begin{tabular}{c|} 
Empreendedor \\
pessoal
\end{tabular} & $\begin{array}{l}\text { "... Eu tenho muito de perfeccionista né, na maioria das } \\
\text { vezes, ai eu falei, bom então eu tenho que ser o melhor na } \\
\text { área...". }\end{array}$ & E5 \\
\hline $\begin{array}{l}\text { Especialista } \\
\text { gerador de } \\
\text { ideia }\end{array}$ & $\begin{array}{l}\text { "Eu acho que a ideia de surgir, talvez seja porque nunca } \\
\text { levantei, trabalhando dentro com alguém, a ideia maior } \\
\text { era o crescimento, então, eu sempre fui uma pessoa assim, } \\
\text { alerta, em termos de crescimento". }\end{array}$ & E6 \\
\hline $\begin{array}{l}\text { Especialista } \\
\text { gerador de } \\
\text { ideia }\end{array}$ & $\begin{array}{l}\text { "E a gente já não conseguia mais tocar uma assistência } \\
\text { técnica por que não tinha peça pras coisas né?! E aí, nesse } \\
\text { momento eu tive um momento de criatividade muito legal, } \\
\text { eu montei um plano assistencial de saúde pra informática, } \\
\text { era Unimicro, você levava o computador gratuitamente, a } \\
\text { gente fazia consulta com ele quantas vezes fosse necessá- } \\
\text { rio. Mas aí a gente cobrava a peça. Então eu cheguei a ter } \\
\text { quase cinco mil clientes nesse cadastro, aí eu abandonei } \\
\text { porque eu não conseguia mais dar suporte". }\end{array}$ & E7 \\
\hline
\end{tabular}

Quadro 5 - Caracterização da tipologia do empreendedor antes do insucesso empresarial Fonte: Pesquisa. 


\begin{tabular}{|c|c|c|}
\hline \multicolumn{3}{|c|}{ Durante o insucesso empresarial } \\
\hline Tipologia & Caracterização & Empreendedor \\
\hline $\begin{array}{l}\text { Empreendedor } \\
\text { pessoal }\end{array}$ & $\begin{array}{l}\text { "Eu não investi na empresa, todo o dinheiro que eu ca- } \\
\text { tei, ao invés de injetar dentro da empresa pra que ela } \\
\text { viesse a crescer, não, eu injetei em mim. Roupa de mar- } \\
\text { ca, carro, é, boa curtição com as meninas que eu queria, } \\
\text { e assim foi indo. Então eu deixei de investir, no cres- } \\
\text { cimento da empresa, ao qual naquele momento foi me } \\
\text { entregue a oportunidade esse foi o fator fundamental, } \\
\text { falta de visão". }\end{array}$ & E1 \\
\hline O lenhador & $\begin{array}{l}\text { "O que você produzia vendia, as lojas tavam procurando } \\
\text { o produto não tinha. Você vendia tudo que fazia... Tinha } \\
\text { quase vinte produtos na linha e eu vendia os vinte, não } \\
\text { tinha nenhum encalhado, então a preocupação é produ- } \\
\text { zir. O que veio trazer as dificuldades foi o relacionamen- } \\
\text { to. Uma vez uma pessoa falou: Ah, vocês estão bem, } \\
\text { lança esmalte de unha, aí o sócio falou: ah não, isso aqui } \\
\text { tá bom, o que tem aí tá bom, não precisamos lançar mais } \\
\text { nada, tamo ganhando bem e tal... Assim começa né?! Ai } \\
\text { já começou uma consequência do desentendimento...". }\end{array}$ & E3 \\
\hline $\begin{array}{l}\text { Formador de } \\
\text { equipe }\end{array}$ & $\begin{array}{l}\text { "Porque eu não sei se o pessoal não acompanha a mi- } \\
\text { nha velocidade de trabalho né, não tem o mesmo ritmo e } \\
\text { acaba descontinuando a coisa e não dando certo, e foram } \\
\text { várias decepções que eu tive na área... por que é uma } \\
\text { área que eu entrei muito que eu não conhecia, eu vim de } \\
\text { uma área completamente comercial e entrei numa técni- } \\
\text { ca, quando o pessoal percebeu que eu não entendia o que } \\
\text { eles faziam, então aí eles se aproveitaram do momento". }\end{array}$ & E4 \\
\hline $\begin{array}{l}\text { Multiplicador } \\
\text { de padrão }\end{array}$ & $\begin{array}{l}\text { “... Daí de motorista passei a técnico de campo comer- } \\
\text { cial, e tocava a escola de música, eu sempre tive dois } \\
\text { empregos, principalmente nas épocas que uma empresa } \\
\text { quebrava, eu tinha que voltar pro mercado de trabalho, } \\
\text { eu tinha que comer né”. }\end{array}$ & E5 \\
\hline $\begin{array}{l}\text { Formador de } \\
\text { equipe }\end{array}$ & $\begin{array}{l}\text { "Eu monto uma equipe de vendedores. Eu comecei a } \\
\text { trabalhar vários vendedores, e já não tinha mais tempo } \\
\text { de sair pra vender, e sim de administrar o outro traba- } \\
\text { lho. Eu cheguei a ter de } 60 \text { a } 80 \text { vendedores, no interior } \\
\text { do estado de São Paulo. Então acredito que até foi pior, } \\
\text { porque o problema maior não foi a administração. Então } \\
\text { passei a ser roubado, pelos próprios vendedores". }\end{array}$ & E6 \\
\hline $\begin{array}{c}\text { Empático } \\
\text { supervendedor }\end{array}$ & $\begin{array}{l}\text { "E aí assim, me tornei mó vendedor de blaster do, do } \\
\text { Brasil né?! Fui homenageado várias vezes. Só que eu } \\
\text { nunca gostei de administração, eu não gostei de ficar lá } \\
\text { dentro sentado, fazendo conta. Então isso foi meu gran- } \\
\text { de erro. Aí chegou o momento que eu tomei pé, que não } \\
\text { descobri que eu tinha vendido muito, ganhado muito, } \\
\text { mas eu tava devendo pra bancos. Tava devendo impos- } \\
\text { tos, e tinha um passivo trabalhista". }\end{array}$ & E7 \\
\hline
\end{tabular}

Quadro 6 - Caracterização da tipologia do empreendedor durante o insucesso empresarial Fonte: Pesquisa. 


\begin{tabular}{|c|c|c|}
\hline \multicolumn{3}{|c|}{ Depois do insucesso empresarial } \\
\hline Tipologia & Caracterização & Empreendedor \\
\hline O hobbysta & $\begin{array}{l}\text { "A minha principal preocupação, é que eu já tô já ficando um } \\
\text { pouco mais velho, não posso mais errar como errei, e minha } \\
\text { preocupação hoje é, não devo, e não posso mais errar". } \\
\text { "Eu não gosto da profissão, eu detesto a profissão de serra- } \\
\text { lheiro, eu posso dizer. Ela quase me matou, por irresponsabi- } \\
\text { lidade minha sim, eu assumo que errei, por não ter me focado } \\
\text { no crescimento dela, mas ela me ensinou". }\end{array}$ & E1 \\
\hline O hobbysta & $\begin{array}{l}\text { "Não quero, não que eu não goste, acho muito bacana, tra- } \\
\text { balho na aviação civil e lido com isso, entendo, continuo } \\
\text { encontrando com meus colegas que são da aviação civil da } \\
\text { área de cargas de transporte de cargas, falo a respeito, mas } \\
\text { assim, só o momento, acabou. Eu acho que é uma forma } \\
\text { de eu me desligar daquela sociedade. Se eu penso, parece } \\
\text { que eu tô alimentando um processo que foi doloroso de } \\
\text { depressão, e esse processo eu não quero mais". } \\
\text { "Passei a ouvir mais a minha força interior, a minha voz } \\
\text { interior, dou mais credibilidade a ela". }\end{array}$ & E2 \\
\hline O hobbysta & $\begin{array}{l}\text { "Embalava os produtos na minha casa lá em Mogi, e } \\
\text { punha no carro, vinha de manhã pro estacionamento, } \\
\text { deixava ali, e o que vendia ficava ali, e fui indo... Co- } \\
\text { mecei trabalhar. E começou melhorar, ai eu pensei 'nós } \\
\text { precisamos arrumar um lugar', porque tinha vezes que } \\
\text { eu ia duas vezes em Mogi, só de manhã saia de casa } \\
\text { com mercadoria". }\end{array}$ & E3 \\
\hline $\begin{array}{l}\text { Multiplicador } \\
\text { de padrão }\end{array}$ & $\begin{array}{l}\text { "Comecei a crescer junto com a companhia, oportuni- } \\
\text { dades de postos fechados, empresas falidas e a empresa } \\
\text { viu a seriedade do nosso trabalho e começou a investir". }\end{array}$ & E4 \\
\hline $\begin{array}{c}\text { Empreendedor } \\
\text { pessoal }\end{array}$ & $\begin{array}{l}\text { "Acho que essa minha empreendedora foi quase que um } \\
\text { jogador, e acreditar no potencial de acertar aquele foco } \\
\text { na frente. O que você quer? Quais são os resultados que } \\
\text { você espera? Depois vem a empreendedora, que forma } \\
\text { a matriz disso aí, e acredita que você pode confiar no } \\
\text { seu potencial, e saber que você que você pode mais que } \\
\text { muita gente". }\end{array}$ & E5 \\
\hline O jogador & $\begin{array}{l}\text { "Nunca me vi sem trabalhar, é o que eu não tenho hoje, } \\
\text { é o prazer de ser milionário. Isso não me passa mais pela } \\
\text { cabeça, o que eu tenho eu já resgatei. Resgatei minha } \\
\text { casa, o meu carro, a minha família, que foi o mais im- } \\
\text { portante. E a minha vida de agora em diante é estudar". }\end{array}$ & E6 \\
\hline Autônomo & $\begin{array}{l}\text { “Meu amigo tinha um centro de treinamento na área de } \\
\text { informática, já me conhecia há alguns anos, me respei- } \\
\text { tava, porque ninguém tem dúvida de como eu sou, e aí } \\
\text { ele me perguntou quanto que eu tava cobrando por hora } \\
\text { de consultoria, eu dei o valor e ele falou: 'Olha, eu te } \\
\text { compro vinte e quatro horas'. Eu não vou ser consultor, } \\
\text { trabalhando pra um único cara eu não vou ser consultor, } \\
\text { né?! Mas aí a necessidade e tal, não sei o que, era uns, } \\
\text { acho que uns quatro, cinco mil. Vai fazer uma grande } \\
\text { diferença quatro cinco mill. }\end{array}$ & E7 \\
\hline
\end{tabular}

Quadro 7 - Caracterização da tipologia do empreendedor depois do insucesso empresarial Fonte: Pesquisa. 
Os quadros de caracterização evidenciam a tipologia mais proeminente a partir dos relatos dos entrevistados. Ressalta-se que os mesmos também poderiam ser caracterizados em outras tipologias, no entanto, para fins de análise dos resultados deste estudo, optou-se por caracterizar cada empreendedor nas diferentes fases - antes, durante e depois do insucesso empresarial - apenas com base na tipologia mais proeminente. Identifica-se que houve mudanças no comportamento e na tipologia dos empreendedores entrevistados. Considerando-se que as tipologias são definidas a partir de características comportamentais, parece coerente afirmar que mudanças no comportamento do indivíduo empreendedor suscitem alterações em sua tipologia.

Esses quadros apresentados servem de apoio para a realização da análise das categorias não a priori deste estudo: excesso de autoconfiança, falta de conhecimento em administração ou na área do negócio, problemas com o sócio, sofrimento emocional, apoio externo e processo de aprendizagem. Essas categorias estão relacionadas com as tipologias encontradas e são apresentadas a seguir conforme o período - antes, durante e depois do insucesso empresarial.

\section{ANTES DO INSUCESSO EMPRE- SARIAL}

\section{Excesso de Autoconfiança}

Esta categoria foi percebida na narrativa dos entrevistados no período anterior à descontinuidade do negócio. Segundo Fillion (1999), a autoconfiança está entre as características mais frequentemente atribuídas aos empreendedores. Essa característica manifesta-se juntamente com a vivência do sucesso, porém, caso seja excessiva, pode provocar um processo de rigidez organizacional dificultando a adaptação da empresa às mudanças ambientais (FINKELSTEIN, 2007), o que evidencia a possibilidade de equívocos na percepção do empreendedor com relação ao seu negócio.

Entre os hábitos dos executivos malsucedidos identificados por Finkelstein (2007), o mais traiçoeiro é a visão que o líder tem de si mesmo e de sua empresa, acreditando que possui total domínio de seu ambiente e utilizando as pessoas como instrumentos. Essa visão pode ser evidenciada no relato de E1: "Na minha idade, se alguém se aproximasse de mim duro, eu com dinheiro no bolso. Humilhava. Então. A minha idade naquela época dezoito, vinte anos, eu tinha o carro que eu sempre quis ter, dinheiro no bolso, e a fonte de renda".

$\mathrm{O}$ excesso de autoconfiança parece estar relacionado à tipologia de E5, no período anterior ao insucesso, classificado como empreendedor pessoal (Quadro 5). Este empreendedor considerava que tinha um bom conhecimento sobre o seu negócio e acabou negligenciando o seu trabalho, conforme ele comenta: "você começa a perder tempo na internet, perder tempo com, com, besteirinhas, sabe, e que você deixe de administrar o seu negócio". Isso parece demonstrar que a autoconfiança em seus negócios permitia que ele tivesse tempo para outras atividades e não se preocupasse com a administração de seu empreendimento.

Neste mesmo raciocínio, Minello (2010) corrobora a ideia de Finkelstein quando afirma que a crença inabalável em si mesmo e nos valores da organização é um aspecto que pode trazer à tona quadros enganosos da realidade ou premissas falsas, ou seja, erros que poderiam ser prevenidos nem chegam a ser questionados, influenciando o processo do insucesso empresarial. Essa situação foi mencionada pelos empreendedores E3 e E7.

Não deu pra enxergar muito erro, porque não dava pra apontar muito erros, porque você começa uma firma com cinco anos e pouco tu faz tudo que nós fizemos, não dá tempo de ver... Sabe por quê? Era assim oh, você produzia 
cem mil batom, vendia cem mil batom, mês que vem você produzia cento e cinquenta, vendia cento e cinquenta, que erro que você vai ver, sabe?! (E3)

Eu acho que os principais erros foram com relação a, a não avaliar as possibilidades de dar errado. Ou seja, acho que era o excesso de confiança, e, e o excesso de confiança eu acho que não é ruim, eu acho que ele só é ruim quando você esquece que tem coisa que não depende de você, né?! Então eu acho que esse é, esse é o erro básico, né?! Tipo fica aquela coisa do eu caio dez vezes levanto cem, mas tem coisa que não depende de você. (E7)

O excesso de autoconfiança aparenta caracterizar um foco psicológico do comportamento do empreendedor que tem reflexo direto no comportamento organizacional. Dessa forma, percebe-se a mudança do seu comportamento quando passa para o período durante o insucesso, em que a frequência da autoconfiança nas narrativas dos empreendedores diminui em relação às encontradas no período anterior ao insucesso.

Falta de Conhecimento

O desempenho ineficiente parece ser oriundo da falta de conhecimento de gestão, o que aparenta contribuir para o surgimento desta categoria, já no período anterior ao insucesso. Nesse sentido, evidencia-se a importância de as pessoas que estão no topo da organização apresentarem uma postura de liderança adequada, ou seja, aplicarem o conhecimento de acordo com as necessidades da empresa e, caso não tenham o domínio necessário, buscarem auxílio. Esta perspectiva é partilhada por Finkelstein $(2004,2007)$, Doltlich e Cairo (2003), Doltlich (2004), Singh, Corner e Pavlovich (2007) e pode ser evidenciada no relato abaixo.

$\mathrm{Na}$ época eu poderia ter chamado um advogado, uma pessoa conhecedora pra estar elaborando contrato, pra dar uma boa assessoria, porque é uma área que eu não conhecia, eu vim de uma área completamente comercial e entrei numa técnica, quando o pessoal percebeu que eu não entendia o que eles faziam, se aproveitaram do momento. (E4)

Ao analisar a perspectiva do empreendedor em estudos de Zacharakis, Meyer e De Castro (1999), percebe-se que os fatores internos são frequentemente mencionados como causa do fracasso de seus empreendimentos. Entre esses fatores, está a estratégia inadequada de gestão resultante da falta de conhecimento, de formação e de experiência na área. $\mathrm{O}$ empreendedor $\mathrm{E} 5$ exemplifica essa ideia:

[...] mas tudo é conhecimento né, aí eu não tinha ideia de administração nenhuma, não tinha ideia de custo fixo, não tinha ideia de nada, e então esse negócio tinha tudo pra dar certo né, mais, assim, total ignorância de negócios administrativos tudo, acabou não virando [...]. (E5)

Ao alinhar essa categoria com as tipologias, o empreendedor E1, conforme descrito anteriormente no Quadro 5, apresenta a tipologia "autônomo" como característica antes do insucesso, baseado nas suas habilidades técnicas sobre o seu negócio. Isso foi o que o motivou a abrir o seu próprio empreendimento, sem considerar a necessidade de conhecimento administrativo, o que pode ter sido um dos fatores que o levou ao insucesso.

Já o empreendedor E2, antes do insucesso, possui características comportamentais da tipologia "multiplicadores de padrão". Nesse caso, o empreendedor reconheceu o negócio da academia de ginástica como uma oportunidade de empreendimento, no entanto, também não levou em consideração o conhecimento necessário em gestão.

Os entrevistados E1 e E2, em seus depoimentos, ilustram as considerações de Longenecker, Simonetti e Sharkey (1999), Singh, Corner e Pavlo- 
vich (2007), Zacharakis, Meyer e De Castro (1999), os quais ressaltam que as causas do fracasso são oriundas da falta de conhecimento técnico e da falta de habilidade em gestão. Partindo desse pensamento, pode-se verificar que a ação somente por impulso, intuição ou oportunidade muitas vezes não é segura, pois a falta de conhecimentos específicos influenciou as etapas seguintes dos negócios dos empreendedores entrevistados.

\section{DURANTE O INSUCESSO EMPRE- SARIAL}

\section{Problemas com os Sócios}

A percepção com relação aos sócios foi saliente nas entrevistas relativas ao período durante o insucesso. Conforme Zacharakis, Meyer e De Castro (1999), é comum ouvir de empreendedores que vivenciaram o insucesso empresarial que seus negócios fracassaram por causa do mercado, do sócio, da falta de conhecimento do negócio, da falta de experiência, de ações governamentais, da concorrência desleal, entre outros.

Quanto aos sócios, Bernhoeft e Castanheira (1995) afirmam que a dinâmica do processo de relação entre eles sofre modificações ao longo do tempo e a convivência pode influenciar o grau de tolerância. No presente estudo, os entrevistados trazem relatos de insatisfação e decepção com os sócios, conforme o relato de E5: "Ah, decepção com pessoas é muito forte né, daí, essa parte de sócios, é, o negócio muda muito quando envolve um pouco de dinheiro né, as pessoas perdem valores, perdem costumes, perdem verdade. É complicado!”.

Em muitos casos, segundo Ferreira e Santos (2008), por falta de profissionalismo e experiência, o empreendedor escolhe pessoas da família ou amigos como sócios, que, na maioria das vezes, não têm as competências necessárias para fazer parte da empresa e podem comprometer o desempenho e a sobrevivência da organização.

É... é essa falta talvez de profissionalismo do outro sócio, não, não na necessidade de se envolver com a atividade, porque eu sabia que não era a área dele, isso eu reconheço absoluto, tendo como um sócio investidor, mas não como um sócio de desempenho de atividades [...]. (E2)

No que tange às tipologias, pode ser evidenciado no Quadro 6, durante o insucesso, que o E3 possui características da tipologia "o lenhador". Essa tipologia sobressaiu quando o entrevistado culpou o sócio por não considerar a opinião de uma terceira pessoa para lançar um novo produto - o esmalte e por acreditar que a produção que eles tinham era o suficiente, começando, assim, uma série de desentendimentos.

Desse modo, verifica-se que a escolha dos sócios ou parceiros com os quais a empresa irá contar merece destaque, pois é dessa relação que depende a harmonia e o equilíbrio da gestão de um empreendimento (FERREIRA; SANTOS, 2008). No caso desses empreendedores, houve um desequilíbrio na harmonia da relação entre os sócios durante o período de insucesso, o que acabou contribuindo para a desestruturação do negócio.

\section{Sofrimento Emocional}

Esta categoria parece ter sido expressiva no período concomitante ao insucesso. Job (2003), ao fazer uma reflexão sobre a centralidade do trabalho na vida das pessoas e o seu significado para as mesmas, evidencia a organização e as condições de trabalho como fatores de sofrimento humano, denominados por ele como fatores de risco. Dentre os propulsores desse sofrimento, podemse evidenciar a pressão e a responsabilidade do trabalho, bem como a atuação do empreendedor frente às situações enfrentadas. Essa atuação pode levar a um segundo fator de risco, correspondente 
à incapacidade de aceitar suas próprias falhas; à falta de tempo para a família e aos problemas que isso pode acarretar para o desempenho de suas funções; e à falta de apoio dos pares e/ou superiores, que pode proporcionar uma falta de reconhecimento dentro da organização, gerando possíveis frustrações e incertezas sobre o futuro, como pode ser visto no relato de E1 e E8, transcritos a seguir.

Isso foi uma das coisas mais brutais, que um ser humano pode passar em matéria profissional, porque você de uma vida profissional maravilhosa, só de êxito de repente você vê, aquilo se desmoronar, como um castelo de areia, que vai, foi se deteriorando, e é o tal negócio, se eu não consigo vender... eu vendi. Sabe que isso aí, foi um abalo moral muito grande, muito grande, você se abate, mais é aquele negócio, sendo o número um da empresa, eu não podia de jeito nenhum me abater, porque aí então, aí então era derrocada, virava pó, tudo. E aí era família, era tudo, mulher filho neto, bisneto, ia tudo, de embrulho. (E8)

Quando eu comecei a quebrar, o que foi mais difícil naquele exato momento foi ter que voltar do início, pra mim ter que recomeçar, eu já não encontrava forças, por que foi difícil chegar até ali. Então pra mim aceitar, que ter que recomeçar novamente, então isso era muito difícil, ter que recomeçar novamente. Isso era difícil. Ter que pisar em cima do meu orgulho, pra ir lá, abaixar a cabeça pra alguém que me aconselhou dizendo: tá vendo, eu não falei pra você que você ia quebrar. Então isso era difícil, muito difícil. Quando eu olhava pra um amigo, que começou no ramo como eu, e via que a oficina dele tava bombando, e que a minha não tinha um serviço, isso também era difícil. Mais o único culpado de tudo isso era eu. (E1)

Nesse sentido, o impacto de adversidades sobre a vida de um indivíduo pode refletir na sua forma de trabalho dentro da organização, pois acaba in- fluenciando sua percepção e sua forma particular de ver e resolver as coisas, como é o caso dos empreendedores que necessitam adaptar-se de forma contínua às adversidades do ambiente. Situações como essa podem tirar o equilíbrio emocional do indivíduo e perturbar sua saúde mental, potencializando o seu próprio sofrimento e podendo afetar de maneira significativa a vida daqueles que estão direta ou indiretamente envolvidos (BARLACH, 2005; HISRICH, PETERS, 2004; MALVEZZI, 1999; FLACH, 1991; ROBB, 2000) ou podendo, até mesmo, levar a situações mais graves ou extremas de perturbação emocional, como: perda de identidade, mendigagem; alcoolismo e depressão; e ideação suicida. Os relatos de E5 e E4 parecem exemplificar essa ideia:

E como eu falei pra você, eu sonhei que com quarenta anos eu ia tá bem, e eu nunca desisti do meu sonho, apesar de quebrar, apesar de todos os percalços, de sofrimento, coloquei a minha família em risco, o meu casamento, mais foi, acreditar que você pode, eu poderia ter chegado melhor, sem tanta dor, sem tanto sofrimento [...] Pra mim acho que família, a coisa que eu vou mais carregar, pra minha vida inteira, é desde a minha mãe que nos apoiou desde a falta do alimento na hora que eu quebrei, a minha esposa que soube entender o momento que eu passei ali, o sofrimento, e sofreu junto e ajudou a, depois a caminhar, andar, a família foi a base de tudo isso. (E5)

No pessoal porque você é... se sente infeliz na sua vida, se sente ela desmoronar, ela sai do seu controle, e emocional também, porque você entra num processo uma junção de coisas, que está acontecendo simultaneamente, parece que é muito pra você suportar. E aí você tem momentos depressivos, momentos que você tem vontade de desistir da vida, mas de vez em quando vem aí alguma força que vem de um lugar aí, que dentro de você tem uma outra vida, e 
eu acho que é essa vida que você tem que viver. Foram tantas as pressões... e essas pressões... levaram a pensamentos ruins... inclusive pensei em suicídio... mas com o tempo consegui tirar isso da cabeça. (E4)

No que tange às tipologias, o sofrimento emocional pode ser relacionado à tipologia "empreendedor pessoal", pois, ao estar somente preocupado com seus ganhos materiais, a quebra de seu empreendimento foi um choque tão intenso que acarretou uma perturbação emocional muito grave. $\mathrm{O}$ entrevistado $\mathrm{E} 5$, que queria ser o melhor da sua área, e o E1, que investiu todo o dinheiro em ganhos pessoais, ilustram essa relação, pois ambos salientam o sofrimento que sentiram ao ter de superar o orgulho e envolver a família nesse processo doloroso.

Pode-se evidenciar que o sofrimento vivenciado pelos empreendedores, devido ao insucesso, foi um processo doloroso que parece ter causado desequilíbrios emocionais. A falta de conhecimento ocultada pelo excesso de autoconfiança, categorias salientadas neste estudo no período anterior ao insucesso, ao ser descoberta durante o choque do insucesso, acarretou esse sofrimento emocional.

\section{DEPOIS DO INSUCESSO EMPRE- SARIAL}

\section{Apoio Externo}

A busca por alianças, apoio da família, rede social e religião é um fator que, aparentemente, emergiu neste estudo, principalmente no que se refere ao período posterior ao insucesso. Barlach (2005) afirma que uma boa figura parental e conexões com uma rede familiar mais ampla, que seja fonte de apoio, são aspectos presentes para pessoas que apresentaram resiliência diante de uma adversidade. Assim, em situações adversas, como o insucesso empresarial, a relação com a família torna-se mais fortemente percebida, como no caso do empreendedor E6:

[...] não tinha local pra tomar banho, não tinha amigos, o dinheiro que fazia na rua com artesanato, bebia, quando dava pra fazer, e ficava viajando, aqui, litoral [...] minha esposa falou 'eu não acredito, porque a gente se conhece desde criança, eu te conheço desde criança, você é um empresário, você é um estudioso, você nunca teve mancha na sua vida, e agora você vai virar mendigo, é inacreditável'. E naquela noite eu decidi que eu ia mudar, e voltamos, passamos a morar juntos de novo. (E6)

Como se pode evidenciar no relato citado, segundo Dell'Aglio e Hutz (2002), a busca por apoio social por razões instrumentais significa a busca por pessoas que possam resolver ou auxiliar a resolver o problema ou ainda que possam protegê-lo do estresse. No caso do insucesso, amigos, pessoas próximas, colegas de trabalho e até mesmo fé funcionam como um fator de apoio para recomeçar. A seguir, salienta-se um trecho que descreve a importância desse fator, mencionado pelo entrevistado E4.

Então o sonho vai acontecer, vai ser impedido por um tempo, vai mais vai ter o tempo certo pra florescer e vai dar certo. Deus não sonhou nenhuma derrota. Deus sonhou eu, sonhou você, sonhou coisas boas, nós vamos dar certo, eu tenho certeza disso. Essa foi a verdade. (E4)

Ainda sobre essa abordagem espiritual, Kubler-Ross (1976) define a busca pela religiosidade como uma das fases do processo de luto e perda, a qual se caracteriza pela espera por uma intervenção divina, por uma solução mágica diante da adversidade vivenciada pelo indivíduo.

Em relação às tipologias, no período após o insucesso, na tentativa de investir todos os recursos possíveis para desenvolver seu negócio, característica comportamental do empreendedor "o hobbysta", o empreendedor E3 mudou de cidade e teve o apoio de seu cunha- 
do para cuidar de seus filhos. No caso do empreendedor E7, depois do insucesso, quando estava sem trabalho, teve o apoio de um amigo que o convidou para fazer consultoria em um centro de treinamento em informática. Nesse sentido, evidencia-se que ele aproveitou o apoio cedido pelo amigo, utilizando as características comportamentais de empreendedor "autônomo" para executar os seus serviços pessoalmente, baseando-se nas habilidades técnicas que ele adquiriu durante a vivência de seu negócio.

É importante comentar que o apoio externo diante das dificuldades ou de situações de insucesso pode influenciar as mudanças no comportamento e na tipologia dos empreendedores. Verifica-se que a maioria dos empreendedores antes do insucesso tinha uma postura comportamental planejada e organizada em relação aos negócios e buscava a satisfação dos objetivos pessoais, dedicando-se de forma intensa aos negócios e ao viver o insucesso voltou-se mais para o apoio de familiares, amigos e fé.

\section{Processo de Aprendizagem}

A aprendizagem foi um processo percebido pelos entrevistados no período posterior ao insucesso. Os erros e fracassos estão presentes, porém, é possível minimizá-los através do processo de aprendizagem com os próprios erros já cometidos. Consequentemente, ao rever sinais de potencial fracasso, é preciso prestar atenção e agir rapidamente para proteger os investimentos e a carreira (FINKELSTEIN 2004, 2007).

Uma, uma coisa muito, aí é uma questão muito de interior né?! É uma força interior. É uma, é uma, é uma nova vida que surge com essas oportunidades, e perceber que os fracassos sejam eles provocados ou não, eles são obstáculos que existem em todos, todos lugares em todas as circunstâncias, acho que a gente tem apenas que aprender a olhar de um outro lado. (E2)
Dependendo da forma como o indivíduo lida com a adversidade e de sua capacidade de enfrentá-la, ele pode aproveitar a situação, neste caso o insucesso empresarial, para se fortalecer por meio da experiência vivenciada e pelo aprendizado gerado por ela (LAZARUS; FOLKMAN, 1994). Essas situações são descritas abaixo, no trecho da fala do empreendedor E4:
Ah, eu acredito que dois aconteci- mentos são muito importantes, assim a falência é muito importante, quan- do eu quebrei eu acho importante, foi quando eu pude parar, analisar aquele momento, refletir, só uma bagagem nova de dívidas e... dá uma experiên- cia, que digo assim, gostaria que as pessoas passassem, acho que gostaria que elas adquirissem essa experiên- cia, lendo mais, participando mais de palestras, estudando mais. (E4)

Ao alinhar o aprendizado com as tipologias, o E6, após o insucesso empresarial, classificado como pertencente à tipologia "o jogador", considera que sua empresa hoje lhe fornece subsídios suficientes para viver bem. Antes almejava ser milionário, entretanto, atualmente diz ter mudado a sua visão, pois já resgatou o que é mais importante, segundo ele - sua casa, seu carro e sua família. De agora em diante, pensa em estudar, o que demonstra que, após a experiência, passou por um momento de reflexão, apresentando uma nova capacidade de discernimento. Essa sequência de atitudes exemplifica o modelo de aprendizagem vivencial de Kolb (1997). Segundo o autor, para o efetivo aprendizado, os aprendizes necessitam de quatro tipos diferentes de habilidades: a experiência concreta (o envolvimento em novas experiências); a observação reflexiva (a reflexão sobre essas experiências e sua observação a partir de diversas perspectivas); a conceituação abstrata (a criação de conceitos que integrem suas observações em teorias sólidas); e a experimentação ativa (a 
utilização dessas teorias para tomar decisões e resolver problemas).

Feita a análise das categorias não a priori individualmente, relacionando -as com as tipologias dos empreendedores desta pesquisa, apresenta-se uma figura síntese dos principais achados deste estudo:
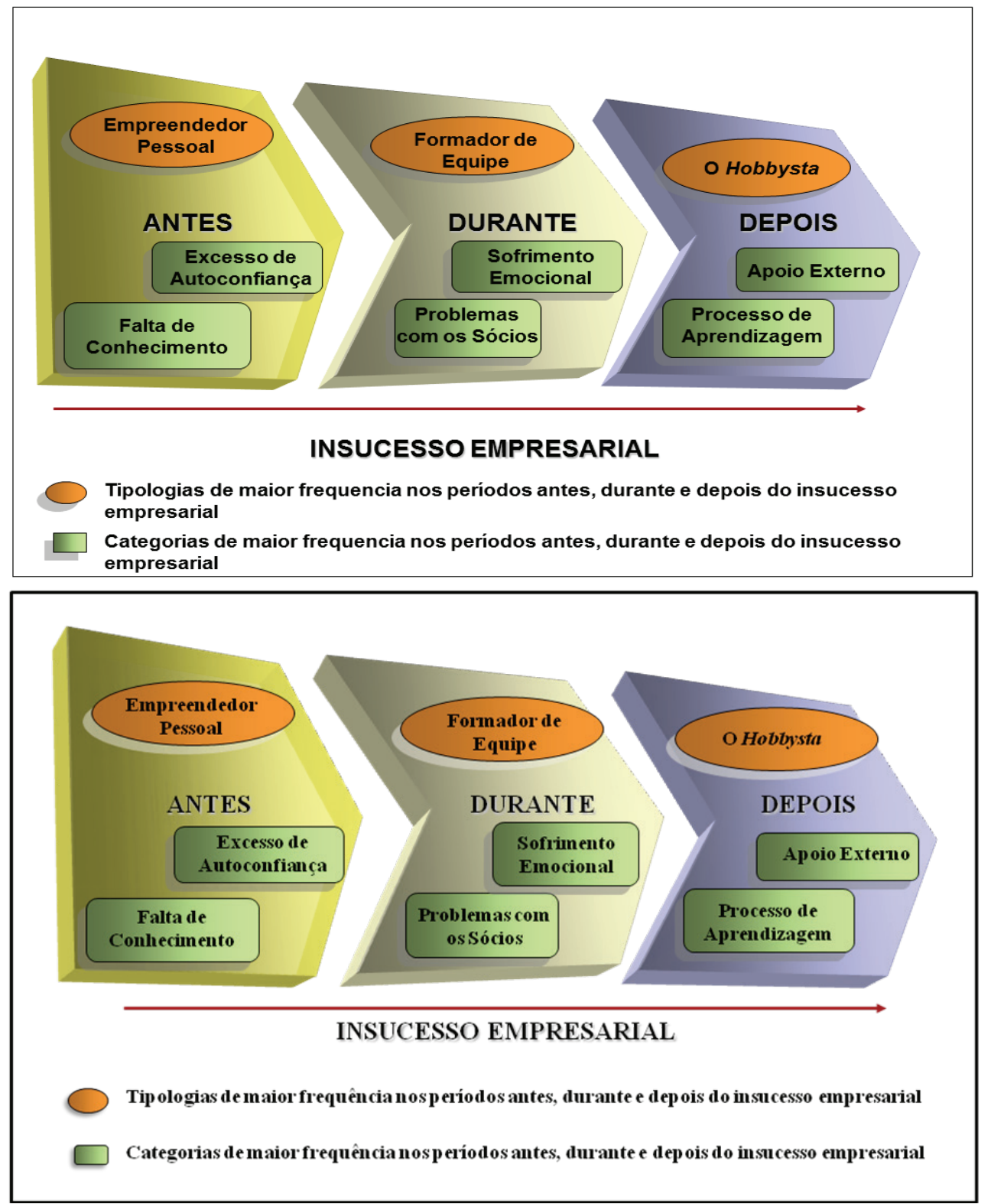

Figura 1 - Mudanças de comportamento e tipologias de empreendedores que vivenciaram o insucesso empresarial

Fonte: Pesquisa.

A Figura 1 sumariza os resultados desta pesquisa sobre as mudanças de comportamento e tipologia de empreendedores que vivenciaram o insucesso empresarial. De acordo com a análise dos dados, as tipologias e as categorias representadas na figura são as mais proeminentes. Isso não significa que determinada categoria ou tipologia aparece somente no período indicado na 
figura, pelo contrário, é possível afirmar que elas têm mobilidade dependendo de cada indivíduo.

\section{Considerações finais}

De acordo com Fillion (1999), ainda não se chegou ao ponto de avaliar uma pessoa e, então, afirmar se ela vai ser bem-sucedida ou não como empreendedora. No entanto, o que se pode dizer é que existem características e aptidões mais comumente encontradas em empreendedores e essas características irão contribuir para a condução do empreendimento ao sucesso ou insucesso. Ao analisar as tipologias dos empreendedores, é possível evidenciar algumas dessas características comportamentais e compreender os motivos que conduziram o empreendedor ao insucesso. Dessa forma, analisou-se o comportamento do empreendedor antes, durante e depois dessa adversidade.

Conforme verificado neste trabalho, os empreendedores entrevistados tiveram mudanças de tipologias em momentos distintos, devido à singularidade comportamental de cada um. Antes do insucesso empresarial, alguns empreendedores tinham como característica a ousadia de aproveitar oportunidades a fim de satisfazer suas necessidades pessoais mesmo com a falta de conhecimento em gestão. Outra característica aparente é o excesso de autoconfiança em alguns empreendedores, deixando seu empreendimento, muitas vezes, sob a responsabilidade de terceiros.

Com o surgimento de problemas, começam os desentendimentos e a projeção da culpa do insucesso nos sócios durante a descontinuidade do negócio. Nesse momento, surge, também, o sofrimento emocional, que parece ter sido um processo doloroso para os empreendedores ao perceberem que tinham perdido seus bens materiais e debilitado a relação com sua família.

Já no momento posterior à descontinuidade, alguns empreendedores obtiveram o apoio externo, através da fé, da família ou dos amigos, e apresentaram um processo de aprendizado pela vivência da descontinuidade do seu empreendimento. Tal processo originou uma capacidade de observação e reflexão de seus atos.

A partir do exposto, verifica-se que o objetivo geral do presente estudo foi alcançado, visto que foi possível, através da análise dos dados, verificar as mudanças de comportamento e tipologia dos empreendedores antes, durante e depois do insucesso empresarial vivenciado pelos mesmos. Conclui-se, assim, que as categorias encontradas neste estudo (excesso de autoconfiança, falta de conhecimento, problemas com sócios, sofrimento emocional, apoio externo e processo de aprendizagem) foram comportamentos que se apresentaram diante do fenômeno estressor - o insucesso empresarial - e que, consequentemente, mudaram o comportamento do empreendedor e sua tipologia.

Apresenta-se como limitação deste estudo o fato de as tipologias apresentarem, de modo geral, características comportamentais positivas em relação ao empreendedor e não referenciarem as possíveis características comportamentais, que podem fazer com que o empreendedor leve o seu negócio ao insucesso, dificultando, muitas vezes, a classificação de uma tipologia para os entrevistados nos períodos concomitante e posterior ao insucesso empresarial. Outro fato limitador é o número de tipologias utilizadas neste estudo, pois é sabido que as características comportamentais do empreendedor são bastante variáveis, já que se trata de comportamento humano. A literatura apresenta outros autores que trabalham com esse tema, o qual pode ser desenvolvido em estudos futuros a fim de complementar e ampliar a visão sobre tipologias de empreendedor diante do insucesso empresarial. 


\section{Referências}

1. BARDIN, L. Análise de Conteúdo. São Paulo, Edições 70, 2011.

2. BARLACH, L. O que é resiliência Humana? Uma contribuição para a construção do conceito. São Paulo, 2005. Dissertação.Instituto de Psicologia, Universidade de São Paulo.

3. BARON, R. A.; SHANE, S. A. Empreendedorismo: uma visão do processo. São Paulo, Thomson Learning, 2007.

4. BERNHOEFT, R. CASTANHEIRA, J. Manual de sobrevivência para sócios e herdeiros. São Paulo, Nobel, 1995.

5. BRUNO A. V.; LEIDECKER, J. K.; HARDER, J. W. Patterns of failure among Silicon Valley high technology firms. In: HORNADAY, J.; TARPLEY, F.; TIMMONS, J; VESPER, K.. Wellesley, Mass: Frontiers of entrepreneurial research. Babson Center for Entrepreneurial Research, p. 677-694, 1986.

6. BRUNO A. V.; MCQUARRIE, E. F.; TORGRIMSON, C. G. The evolution of new technology ventures over 20 years: patterns of failure, merger and survival. Journal of Business Venturing 7, p. 291-302, 1992.

7. COOPER, D. R.; SCHINDLER, P. S. Métodos de Pesquisa em Administração. $7^{\mathrm{a}}$ ed. Porto Alegre, Bookman, 2003.

8. DELL'AGLIO, D. D.; HUTZ, C. S. Estratégias de coping e estilo atribucional de crianças em eventos estressantes. Estudos de Psicologia, 7 (1) p. 5-13, 2002.

9. DOLABELA, F. Oficina do empreendedor. São Paulo, Cultura, 1999.

10. DORNELAS , J. C. A. Empreendedorismo: transformando ideias em negócios. Rio de Janeiro, Elsevier, 2008.

11. DOTLICH, D. L.; CAIRO, P. C. Por que os executivos falham? Rio de Janeiro, Elsevier, 2003.

12. DOTLICH, D. L. Os 11 compor- tamentos que tiram os executivos dos trilhos. In: VOGL, A. J. Anatomia do fracasso. HSMManagement, V. 1, n. 42, p. 142-149, 2004.

13. FERREIRA, A. B. H. Novo Aurélio Século XXI: o dicionário da língua portuguesa. Rio de Janeiro, Nova Fronteira, 1999.

14. FERREIRA, L. F; SANTOS, S. A. Mortalidade Precoce: uma análise das micro e pequenas empresas de São Paulo. In: V ENCONTRO DE ESTUDOS SOBRE EMPREENDEDORISMO E GESTÃO DE PEQUENAS EMPRESAS. São Paulo, 2008.

15. FILION, L. J. Empreendedorismo: empreendedores e proprietários-gerentes de pequenos negócios. Revista de Administração, São Paulo, v.34, n.2, p. 05-28, abril/junho, 1999.

16. FINKELSTEIN, S. Os sete hábitos dos executivos "espetacularmente malsucedidos". In: VOGL, A. J. Anatomia do fracasso. HSMManagement, V. 1, n. 42, p. 142 - 149, 2004.

17. FINKELSTEIN, S. Por que executivos inteligentes falham. São Paulo, Makron Books, 2007.

18. FLACH, F. Resiliência: a arte de ser flexível. São Paulo, Saraiva, 1991.

19. FLECK, D. Archetypes of Organizational Success and Failure. Brazilian Administration Review (BAR), Curitiba, v. 6, n. 2, art. 1, p. 78-100, April/June, 2009.

20. GREATTI, L. Perfis Empreendedores: Análise comparativa das trajetórias de sucesso e fracasso empresarial. Maringá, 2003. Dissertação. Mestrado do Programa de Pós-Graduação em Administração da Universidade Estadual de Maringá e Universidade Estadual de Londrina.

21. GEM. Empreendedorismo no Brasil. Global Entrepreneurship Monitor, 2010.

22. HISRICH, R. D.;PETERS, M. P. Empreendedorismo. Porto Alegre, Bookman, 2004.

23. JOB, F. P. P. O sentido do trabalho e 
a importância da resiliência nas organizações. São Paulo, 2003. Tese. Doutorado na Escola de Administração de Empresas da Fundação Getúlio Vargas.

24. KÜBLER-ROSS, E. K. On Death and Dying. Macmillan Company; First Ed, 16th Print edition, 1976.

25. KOLB, D. A Gestão e o Processo Aprendizagem. In: STARKEY, K. Como as Organizações Aprendem. São Paulo: Futura, 1997.

26. LAZARUS, R.; FOLKMAN, S. Cognitive Appraisal Processes. In: Estresse, Appraisal and Coping. Springer Publishing Company, New York, 1994, Cap. 2, p. 22-54.

27. LONGENECKER, C. O.; SIMONETTI, J. L.; SHARKEY, T. W. Why organizations fail: the view from the front-line. Management Decision. Vol. 37 n. 6, p. 503-513, 1999.

28. MALVEZZI, S. Psicologia organizacional. Da administração científica à globalização: uma história de desafios. In: MACHADO, C; MELO, M.; FRANCO, V.; SANTOS, N. Interface da Psicologia. Portugal: Universidade de Évora, 1999.

29. MINELLO, I. Resiliência e Insucesso Empresarial - Um estudo exploratório sobre o comportamento resiliente e os estilos de enfrentamento do empreendedor em situações de insucesso empresarial, especificamente em casos de descontinuidade do negócio. São Paulo, 2010. Tese(Doutorado no Programa de Pós-graduação em Administração) Faculdade de Economia, Administração e Contabilidade da Universidade de São Paulo.

30. MINER, J. B. Evidence for the Existence of a Set of Personality Types, Defined by Psychological Tests, that Predict Entrepreneurial Success. In: Frontiers of Entrepreneur Research. Edition, Babson College, 1996. Disponível em: www.babson.edu/entrep/fer/papers96/ miner/ Acesso em: 20.01.2011.
31. PEREIRA, H. J. Motivos de sucesso e de fracasso empresarial. In: PEREIRA e SILVA, H. J.; SANTOS, S. A. Criando seu próprio negócio: como desenvolver o potencial empreendedor. Brasília: Ed. SEBRAE, 1995, p. 271-278.

32. RESENDE, E. O papel dos empresários no desenvolvimento do Brasil: suas 12 competências e 5 incompetências. São Paulo, Summus, 2008.

33. RICHARDSON, R. J. Pesquisa Social: métodos e técnicas. $3^{\text {a }}$ ed. São Paulo, Atlas, 2008.

34. ROBB, D. J. Building resilient organizations. OD Practitioner, v. 32, n. 3, 2000.

35. ROBINSON, S. Business failure rates: a look at sex and location. Academy of Entrepreneurship Journal. v13, n1; Entrepreneurship p. 45, 2007.

36. SAMPIERI, R. H.; COLLADO, C. F.; LUCIO, P. B. Metodologia de pesquisa. São Paulo, McGraw-Hill, 2006.

37. SCHUMPETER, J. A. Capitalismo, socialismo e democracia. Zahar, Rio de Janeiro, 1984. (Obra original publicada em 1942 e traduzida por S. G. de Paula).

38. SINGH S.; CORNER, P.; PAVLO$\mathrm{VICH}, \mathrm{K}$. Coping with entrepreneurial failure. Journal of Management \& Organization. v. 13, p. 331-344, 2007.

39. VESPER, K. H. Perspectives on Entrepreneurship. In: New Venture Strategies. Englewood Cliffs: Prentice Hall, 1980. Cap. 1, p. 1-26.

40. WHETTEN, D. A. Organizational Decline: A Neglected Topic in Organizational Science. Academy of Management Review. v. 5. n. 4. p. 577-588, 1980.

41. ZACHARAKIS, A. L.; MEYER, G. D.; DE CASTRO, J. Differing perceptions of new failure: a matched exploratory study of venture capitalists and entrepreneurs. Journal of Small Business Management. ABI/INFORM Global p. 1, v. 37, n. 3, 1999. 